\title{
Contribution of Wild Collected Underutilised Crops in Rural Food and Income Security in Sri Lanka
}

\author{
A. Bandula ${ }^{1 *}$, A. De Silva ${ }^{1}$, P. Oreiley ${ }^{2}$, A.S. Karunarathne ${ }^{1}$ \\ ${ }^{I}$ Faculty of Agricultural Sciences, Sabaragamuwa University, Sri Lanka \\ ${ }^{2}$ Crops for the Future Research Centre, University of Nottingham Malaysia Campus, Malaysia \\ *aroshb@yahoo.com
}

\begin{abstract}
This study focused on investigation of role of wild collected underutilised crops (UC) in rural food and income security with special concern to the availability of those crops at respective village markets. It analysed the availability of wild collected products in the selling stocks of traditional sellers in respective village markets. Wellawaya Divisional Secretariat Division in Moneragala district in Uva Province of Sri Lanka was seleted for the study. Rapid market chain analysis was the principal tool equipped for this investigation. Data collection was conducted by using primary data collection methods mostly under uncontrolled environments. Number of key informant interviews with upstream agents, focus group discussions with collectors and informal discussions with few sellers were done. In addition, a few telephone interviews were conducted with key agricultural actors in the area.
\end{abstract}

Galsiyabala, Palu, Weera, Polpala, Binkohoba, Kithual products and curry leaves (Karapincha) were the key wild collections available in the markets. However, the contribution from the forest varied from around (40\% to 100\%). In general, males engage in wild collection by making significant damages to those trees due to falling of trees and cutting main branches. Reasonable proactive strategies are not yet adapted to ensure sustainable utilisation of wild resources rather than penalties by courts when collectors are captured by Forest Department officers. People practice this as a souces of part-time seasonal income. Though income is seasonal, they receive higher values by selling some traditional medicinal products under informal fixed prices. The price of all other products is determined by traders where collectors have minimum bargaining power in this context.

Keywords: Underutilised crops, Wild collections, Rural households, Food security, Income security 